\title{
Constructing environmentalist identities through green neoliberal identity work
}

\author{
Autumn Thoyre ${ }^{1}$ \\ Colgate University, USA
}

\begin{abstract}
To advance understandings of how neoliberal ideologies are linked to peoples' everyday environmentalist practices, this article examines processes through which green neoliberal subjects are made. Bringing together critical perspectives on green neoliberalism and symbolic interactionist perspectives on identities, I develop the concept of green neoliberal identity work, a mechanism through which neoliberal environmentalist subjects are produced. I use environmentalists' promotions and uses of compact fluorescent light bulbs (CFLs) as a case study, and employ mixed qualitative methods and grounded theory analysis. Data were collected in North Carolina through interviews, participant observation, and texts. The data reveal four generic patterns of green neoliberal identity work: celebrations and renunciations of particular technologies, inclusive-talk, performing moral math, and technological progress-talk. These patterns show that framing green neoliberal subject formation through the lens of identity work illuminates how these subjects form themselves through micro-level social processes, and opens up different ways of thinking about resistance.
\end{abstract}

Keywords: environmentalism, neoliberalism, identity work, subjectivities, identities

\section{Résumé}

Pour faire avancer la compréhension de la façon dont les idéologies néolibérales sont liés à des pratiques environnementalistes quotidienne, cet article examine les processus permettant à des sujets néolibérales verts sont faites. Apporter des perspectives critiques sur néolibéralisme vert, et l'interactionnisme symbolique sur les identités, je développe le concept de travail d'identité néolibérale vert, un mécanisme par lequel les sujets écologistes néolibérales sont produites. Je utilise les promotions et les utilisations des ampoules compactes fluorescentes (LFC) par des écologistes comme une étude de cas, avec les méthodes qualitatives mixtes, et «grounded theory». Les données ont été recueillies en North Carolina, États-Unis à travers des entretiens, observation participative et des textes. Les données révèlent quatre modèles génériques du travail identitaire néolibérale vert: célébrations et renoncements de technologies particulières, la parole inclusif, effectuer un mathématique morale, et parler de progrès technologique. Ces tendances montrent que le cadrage de la formation du sujet néolibéral verte, à travers la lentille de identité, éclaire la façon dont ces sujets se forment par des processus sociaux au niveau micro. Il ouvre différentes façons de penser de la résistance.

Mots-clés: environnementalisme, le néolibéralisme, le travail de l'identité, des subjectivités, des identités

\section{Resumen}

Este artículo avanza nuestro conocimiento sobre como ideologías neoliberales están vinculados a las prácticas cotidianas ambientalistas, por medio de una examinación de los procesos de formación de subjetividades neoliberales "verdes". Combino perspectivas criticas hacia neoliberalismo verde con el interaccionismo simbólico para elaborar el concepto de "trabajo de identidad neoliberal verde", que es un mecanismo por lo cual los sujetos neoliberales están formados. Utilizo métodos cualitativos mixtos y "teoría anclada" para entender el estudio de caso de la promoción y uso de las "lámparas compactas flourescentes" (CFLs). Los datos fueron recogidos en el estado del Norte de Carolina, Estados Unidos de America, a través de entrevistas, observación participativa, y textos. Los datos muestran cuatro formas genéricas de "trabajo de identidad neoliberal verde": celebraciones y renuncios de tecnologías especificas, discursos incluyentes,

\footnotetext{
${ }^{1}$ Dr. Autumn Thoyre, Visiting Assistant Professor, Department of Geography, Colgate University, Hamilton, NY 13346, USA. Email: authoyre "at" gmail.com. I would like to thank the Royster Society of Fellows at the University of North Carolina at Chapel Hill for financial support while I conducted this research. I also thank Sherryl Kleinman, Elizabeth Havice, and Martin Doyle for helpful suggestions on earlier drafts of this paper and JPE editor Casey Walsh and the anonymous reviewers for their valuable comments. Finally, I would like to thank the study participants, without whom this research would not have been possible.
} 
matemáticas morales, y discursos de progreso tecnológico. Nuestro acercamiento ilumina la manera en que los sujetos se forman a través de microprocesos sociales, y abre paso a nuevas maneras de entender la resistencia.

Palabras claves: ambientalismo, neoliberalismo, trabajo de identidad, subjetividades, identidades

\section{Introduction}

The question of how people become different kinds of environmentalists is important to building more sustainable communities. Much of the research addressing this question has focused on the 'determinants' of pro-environmental behaviors (like recycling or voting 'green'), including demographics and holding particular values (e.g., Bamberg and Moser 2007; Stern 2000; Thoyre 2011). A separate line of research has focused on environmentalists as subjects within neoliberal economic systems. Neoliberal ideologies have been documented in the discourses of many environmental movements (e.g. Guldbrandsen and Holland 2001; Roff 2007; Slocum 2004a). Because they focus on individualism, consumerism, and private actions, a number of everyday pro-environmental actions, including home energy conservation and efficiency, consuming organic, local food, and bicycling instead of driving (e.g. Hinchliffe 1996; Horton 2003; Rutland and Aylett 2008) can be seen as neoliberal ${ }^{2}$ environmentalist practices (McCarthy and Prudham 2004). The objective of the present study is to contribute to analyses of the processes through which neoliberal ideologies are linked to everyday neoliberal environmentalist practices, a topic that is not yet fully understood (Agrawal 2005: 210; Barnett et al. 2008), particularly at the micro-level of everyday social interactions.

To study these processes, this research is focused on environmentalists' meaning-making, promotions, and uses of the energy efficient Compact Fluorescent Light bulb (CFL). ${ }^{3}$ The CFL can be seen as an emblematic object ${ }^{4}$ of green neoliberal subjectivities and practices which emphasize the consumption of things to protect the environment. Slocum (2004b) identified CFLs as a "boundary object" that city governments use to "bring climate change home" in discourses creating green neoliberal subjects in her research. She found that energy efficiency objects like CFLs are central to green neoliberal discourses because they focus on "cost saving as the gatekeeper of possibility" in energy efficiency places and they individualize responsibility for climate action.

CFLs follow the tradition of incandescent light bulbs in meaning much more than light. The incandescent light bulb, for instance, has long been a symbol of modernity in the home, particularly modern electricity. During the Depression, the U.S. government's Rural Electrification Administration famously used images of incandescent light bulbs to promote electricity through Lester Beall's posters (MoMA 2012). Today, people call electricity losses "blackouts" (Nye 2010). Even their common use to signify 'aha!' moments, inventions, or ideas can be linked to a long history of light bulbs as symbols of novelty, speed, convenience, and modernity. The image of the CFL symbolizes a certain kind of modernity, what Hajer (1995) would call "ecological modernization", characterized by extensive adoption of home green technologies, in line with neoliberal ideologies.

This research is focused on the subset of environmentalists who consume objects like CFLs in part 'for' the environment. The idea that using CFLs would help the environment was stated by the participants in the research themselves in interviews or was observed through participant observation or analysis of environmental NGO websites. As I will show, it was common for environmental organizations to promote

\footnotetext{
${ }^{2}$ Calling them 'neoliberal', does not imply the objects used or actions performed are inherently wrapped up in neoliberal ideologies or that such ideologies are the only reasons people perform these practices. Instead, it means they share the characteristics of individualization of responsibility, emphasis on the private rather than public sphere, and consumerism that are common to other neoliberalizations of activism (e.g. McCarthy and Prudham 2004).

${ }^{3}$ Invented in 1976, the earliest CFLs often had short lifetimes and poor lighting quality (Sandahl et al. 2006). CFLs represented 1\% of the U.S. lighting market in 2000, rising to 23\% in 2007 in part because of promotions by electricity companies and "big box" stores (U.S. DOE 2009). The best current CFLs use one-quarter of the electricity to produce the same lumens as comparable incandescents (U.S. EPA 2008) and last eight times longer (Creyts et al. 2007: 35).

${ }^{4}$ At the start of this research, it was not assumed that CFLs were guaranteed to be used or framed in neoliberal ways; instead, it was assumed that their use and promotions were likely to involve neoliberal environmental practices because their use emphasizes individualism, the private sphere, and consumerism and because of the results of others' research on CFLs and green identity work.
} 
CFLs in the name of climate change mitigation and for environmentalists concerned with climate change to use CFLs. While people may perform environmental practices, like changing their light bulbs to CFLs for many reasons, I found that making and claiming identities is one of them.

Through this research into CFL meaning-making, use, and promotion by environmentalists, I found that individuals and groups of environmentalists use CFLs in part to create and claim green neoliberal identities. I develop the concept of green neoliberal identity work, a process through which groups and individuals construct and claim such identities and a mechanism through which neoliberal ideologies are linked to everyday environmental practices. I develop this concept by bringing together insights from critical scholars of green neoliberalism and symbolic interactionist sociology to expand our understanding of the mechanisms through which green neoliberal subjects are formed. I used data from interviews, participant observation, and texts about environmentalists' promotions and uses of CFLs to reveal five generic patterns of green neoliberal identity work. Framing environmental subject formation in terms of these five micro-level processes can help scholars to better understand the mechanisms through which neoliberal ideologies become linked to everyday environmentalist practices. It can also help researchers and activists to better understand resistance to neoliberal logics among environmentalists, by suggesting what 'critical green identity work' might encompass, and the ways that the same object - even if it appeared to be quintessentially neoliberal at the outset - can be used to make identities differently.

\section{Analytical framework}

How do people become neoliberal environmentalists? In other words, how do neoliberal ideologies become linked to peoples' everyday environmentalist practices such as buying energy-efficient light bulbs and other green consumptive acts? I bring together two perspectives, critical perspectives on green neoliberalism and symbolic interactionist perspectives on identities, to add to our understanding of these questions.

\section{Critical perspectives on the green neoliberal subject}

Scholars of neoliberalism have shown that many groups are subject to neoliberal economic ideologies. Neoliberalism is considered the form of the U.S. economic system since the 1970s, and a class project that seeks to restore rates of accumulation to elites at a time of declining profitability (Harvey 2005: 19). Neoliberal ideologies prioritize free movement of capital (Harvey 2005: 11), market forces over state decisions about resource allocation (McCarthy and Prudham 2004), individuals' rights and responsibilities, and private property (Heynen et al. 2007: 10, 287). Much of the work on neoliberal subjectivities has its roots in Foucauldian ideas of power as productive of subjects (Foucault 2007) who self-discipline (1995), so that even small, private actions like changing one's light bulb are involved in power relations. Broader neoliberal ideologies "of citizenship and social action are discursively repackaged in the image of homo-economicus, the ideal, entrepreneurial, self-made individual" (McCarthy and Prudham 2004). Using Foucault's ideas about power, subjectivity, and governmentality, scholars have shown that neoliberalism has produced subjects who "shop for change" (Johnston and Szabo 2011) and are encouraged to think of themselves as consumers first rather than other kinds of citizens (Guthman and DuPuis 2006). Because neoliberalism is not allencompassing or the same everywhere (Larner 2003; Katz 2005), it is important to trace how neoliberal ideologies operate on the ground and how they inform environmentalist subjectivities.

Green neoliberal subjects are a type of neoliberal subject oriented toward environmental concerns, yet still subject to neoliberal ideologies of marketization, privatization, and consumption-as-social-change. Neoliberalizations of socio-natures are complex and have been shown to encompass multiple trends (Bakker 2010). Green neoliberalism generally refers to the "'greening' of capitalist institutions like corporations and international trade organizations (Beder 2002: 177; McCarthy and Prudham 2004; McCarthy 2007) and the neoliberalization of environmentalist organizations (Guldbrandsen and Holland 2001; Slocum 2004b). "Turfgrass subjects" have been produced as caretakers of grass subject to neoliberal logics, in part through community norms of lawn care in cities (Robbins 2007: 130). Much of the research on energy and climate change subjects uses the lens of governmentality to show how governments create green subjects who focus on individualized carbon emissions reductions (Rutland and Aylett 2008), consumption of energy efficiency products (Slocum 2004a), and home energy conservation practices (Hobson 2013). Neoliberalizations often 
cause environmental degradation (Prudham 2007), but they can also improve environmental quality (Bakker 2005) or go either way (Bakker 2010). There are hazards in the "co-optation" of environmental movements and subjectivities by neoliberal logics (Gulbrandsen and Holland 2001), as neoliberalized environmentalist subjects may damage democracy (Slocum 2004a), diminish a sense of responsibility among activists (Hinchliffe 1996), and widen inequalities (McCarthy 2007). Dowling, reviewing the literature on climate change activist subjectivities, found that they both help and hurt inequalities (Dowling 2010).

In these ways, scholars of green neoliberalism have theorized how macro-level political and economic forces have helped to create neoliberal subjects who act in ways that tend to privilege capitalist class interests. Yet this literature has not yet completely theorized how these subjects are formed (Agrawal 2005: 210); in particular, we do not yet fully understand the micro-level mechanisms through which these subjects are created through everyday interactions. Much research has emphasized that environmental campaigns reflect larger neoliberal logics (campaigns could be seen as part of subcultural identity work; see below). For example, Guldbrandsen and Holland (2001) found that some local environmental organizations have adopted neoliberalized discourses as they have become 'hybrid' groups, representing both private (capitalist) and public (environmental) interests. Hinchliffe (1996) argues that a UK governmental campaign to encourage pro-environmental actions individualized responsibility, devolving it to the household level. Often the green neoliberal subject is said to be "enrolled", or, following Althusser, they are "interpellated" into the project of neoliberalism (c.f. Barnett et al. 2008; Robbins 2007). As a result, green neoliberal identities are sometimes assumed to be already-formed, static, or simply reflective of larger neoliberal logics, rather than being produced by and helping to reproduce such discourses in complex ways.

\section{Symbolic interactionist perspectives on identity work}

The symbolic interactionist (SI) perspective can add to our understanding of the mechanisms through which neoliberal environmentalists are formed because it is particularly sensitive to micro-level, social psychological processes, helping us understand the processes through which identities are constructed and reconstructed through everyday practices. SI is a field of sociology that grew out of the pragmatist philosophy of George Herbert Mead. As laid out by one of its founders, Blumer (1969: 2), this social constructionist perspective assumes that together people create meanings for themselves, others, and things. People communicate these meanings to each other through processes such as teaching and learning (p12). Individuals' actions, for example their use of objects, arise from "an interpretative process" through which people draw on these socially created meanings (p2). Symbolic interactionists thus build their ideas about how identities are formed from the underlying idea that together people create and interpret these meanings (p2).

An example useful for thinking about environmentalists as subjects can be found in Becker's (1953) classic work on how people become marijuana users. Becker noted that many of those researching drug behaviors focused on the social psychological determinants of those behaviors. Such scholars believed that people became marijuana users primarily because of pre-existing socio-economic and behavioral traits. In contrast, Becker's use of an SI perspective meant he assumed:

...that the presence of a given kind of behavior is the result of a sequence of social experiences during which the person acquires a conception of the meaning of that behavior, and perceptions and judgments of objects and situations, all of which make the activity possible and desirable. (Becker 1953: 235, emphases mine)

Becker found that marijuana users had to learn how to use marijuana for pleasure: veteran users taught beginners how to identify the bodily sensations they were experiencing while smoking as pleasurable experiences. As a result, Becker showed that even something as seemingly biochemical and psychological in nature as using drugs had clear social components.

Symbolic interactionists focus on the ways that identities are formed through social processes, which are often about everyday communications, including teaching. Such scholars conceptualize identity as a way that people present themselves to claim characteristics that are tied to self-esteem; it is "a sign that evokes 
meaning" to others (Schwalbe and Mason-Schrock 1996: 115; emphasis theirs). Similar to Becker's case, much of the current research on environmentalist behaviors has focused on its attitudinal, behavioral, and socio-economic determinants (such as what determines whether people use CFLs, e.g. Bladh and Krantz 2008). An SI perspective, in contrast, emphasizes the micro-level social processes through which people build environmentalist identities and learn from each other. Environmentalist can be seen as a type of "moral identity" whereby a person's ideas about whether they are morally "good" or "bad" are tied to the maintenance (or belief in the maintenance) of the identity (Kleinman 1996: 5), so the success people have in accomplishing this identity is likely to be tied to feelings of self-worth. Such moral identities form part of how people see themselves and influence how they judge the relationship between their sense of self and their own actions (Aquino and Reed 2002).

To better understand the micro-level processes through which environmentalist identities are constructed, the SI analytic 'identity work' is useful. Identity work is "anything people do, individually or collectively, to give meaning to themselves and others"; people use the resources available to them to accomplish identities through identity work (Schwalbe and Mason-Schrock 1996: 115). Such identity formation includes both nonverbal "gestures, acts, dress, and appearances" (Hunt and Benford 1994) and verbal elements, as in identity talk (e.g. Snow and Anderson 1987). Calling identity talk and other acts that claim, define, maintain, repair, contest, and police identities work calls attention to how the processes of identity-making can fail and how successful identity-making often requires "care and skill" (Schwalbe and Mason-Schrock 1996). Scholars have further distinguished subcultural from individual identity work, since identities can be collective (Smith 2013) or personal (Snow and Anderson 1987). Groups do subcultural identity work to construct collective identities, providing the resources in terms of "signs, codes, and rites of affirmation" from which individuals draw to do the individual identity work of constructing personal identities (Schwalbe and Mason-Schrock 1996: 113). We can expect, then, that environmental groups and leaders may be the ones 'teaching' people how to be environmentalists, in a way parallel to Becker's example. In this way, using both scales of identity work can help us to better understand the ways that macro-level ideologies and political economic forces are linked to individual identities and practices used to enact those identities.

Little study has been done by SI researchers to understand the identity work performed by environmentalists. While science and technology studies researchers have shown how everyday practices like showering take on green meanings through social interactions in ways that could be seen as reflecting subcultural identity work processes (Shove and Walker 2010), those processes themselves have not been fully examined. The main studies of environmentalist identity formation have emphasized that making and claiming environmentalist identities is about the consumption and use of material things. Horton (2003: 64) examined how people use objects like organic food and bicycles, or avoid using objects like cars and TVs, to perform their identities as environmentalists. He argues that the conspicuous consumption of these everyday objects is part of how environmentalists "earn 'green distinction', the markings of a green identity." Slocum's (2004b) work on climate change campaigns, although not using the concept of identity work directly, suggests that environmental organizations often use objects like CFLs and polar bears strategically as a resource for subcultural identity work to motivate action. Such research suggests that while talk is likely to be important to environmental identity-making, it may be overshadowed in importance by the use and display of material objects. Thus it is important to understand better how people use environmental objects to make their identities to better understand the micro-level processes through which people become environmentalists. This previous SI work thus lends support to the idea that an object like the CFL can be a useful center of analysis for understanding environmentalist identity work.

\section{Bringing critical green neoliberalism and symbolic interactionism together}

When scholars study neoliberalizations of environmental discourses, people, and practices, they tend to view the environmentalist as a subject (Guldbrandsen and Holland 2001; Slocum 2004a; Robbins 2007), whereas when SI scholars study everyday processes of making environmentalists, they tend to view environmentalist as an identity (Horton 2003; Saunders 2008). Little work has bridged the two, yet they are generally compatible perspectives. Both identities and subjectivities can be complex, ambiguous, and conflicting. Both critical perspectives on neoliberalism and SI theories are social constructionist and, although 
they do it differently, both are attentive to the interests served by various processes and the ways that particular constructions of subjectivities/identities are influenced by current power relations. SI work can complement that of green neoliberalism scholars who have been conscious of power relations within capitalism. For example, Schwalbe and Mason-Schrock (1996: 139) emphasize that SI research on identity work analyzes "the place where people, through expressive behavior and face-to-face interaction, both reproduce and resist larger social arrangements." They stress that the ways people make and claim identities "are enabled and constrained by the conditions under which people act."

I propose that we view the particular type of identity work through which neoliberal environmentalist subjects are constructed as green neoliberal identity work. It is the work of claiming, defining, maintaining, repairing, contesting, and policing green neoliberal identities. Based on what is already known about these neoliberal environmentalist subjectivities, I argue that the consumption of things within neoliberal logics of free markets, private property, and individualized action is central to this identity construction; this assumption motivates the choice of case study.

\section{Research approach}

To understand both the individual and subcultural identity work of buying, using, displaying, and talking about CFLs, particularly since other research has suggested that subcultural identity work helps create the ideological and other resources that individuals use to create their personal identities, I collected several different types of data from June 2010 to January 2013. The study received IRB approval and care was taken throughout the research process (including during data collection and analysis, as well as writing) to protect the anonymity of the interviewees. I interviewed 15 environmental activists in North Carolina, including six who were formal leaders of local environmental NGOs (ENGOs) or environmental committees, seven who were active members of such organizations/committees, and two who were not active members in any group. I gained access to these individuals via participant observation at public hearings at the North Carolina Utilities Commission and through the 'snowball' method (Lofland et al. 2006: 43). ${ }^{5}$ I contacted people who made public statements to the Commission about the importance of energy efficiency for helping mitigate climate change and other environmental problems; I then asked those interviewees to suggest people they knew who might be interested in being interviewed and who also were doing energy efficient actions in their homes for 'environmental reasons', broadly construed. I began each interview by asking what the interviewee did in their everyday lives that made them think of the environment, and they then told me about actions they did that they framed as helping to reduce their impact on the environment. For these reasons, 'environmentalist' was an identity defined by the interviewees rather than imposed on them, but all interviewees did at least a few home energy conservation actions (such as using CFLs, line-drying laundry, walking to work instead of driving, and others) at least in part, they said, 'for the environment.' Interviews were semi-structured, recorded, transcribed, and lasted 1-2.5 hours.

To understand both scales of identity work (subcultural and individual), I observed the ways environmentalists discussed CFLs in groups through 55 hours of participant-observation. This data is complementary to the interview data (Emerson et al. 1995: 12). I conducted the participant observation at public energy and environmental meetings, and hearings in North Carolina. ${ }^{6}$ During the events, I briefly interviewed 37 energy and environmentalist employees and volunteers about their personal or their organizations' views on energy efficiency and/or CFLs. ${ }^{7}$

To analyze subcultural identity work more explicitly, in addition to the interviews with ENGO leaders in NC, I also analyzed texts that ENGOs have produced as resources about CFLs; such resources are likely to represent some of the types of subcultural resources available for identity-making by individuals. I collected websites, letters, and emails from the 'big ten' mainstream U.S. ENGOs (Center for Media and Democracy

\footnotetext{
${ }^{5}$ The interviewees included 10 women, five men; all were white; they ranged in age from their 20s-80s; three had a household income at or below $200 \%$ of the NC poverty line; eight were either wealthy or upper middle class, four had wealth levels in between. All have pseudonyms in this paper. All interviewees signed informed consent forms before these interviews were conducted.

${ }^{6}$ The events included an Earth Day celebration, an energy efficiency education fair, climate activist rallies, public utility commission hearings on state electricity issues, and professional clean energy conferences.

${ }^{7}$ Roughly half men, half women; all white but one; aged 20s-60s.
} 
2011). ${ }^{8}$ I focused on the 'big ten' groups because they represent much of the mainstream, national, public environmental discourses in the U.S. I collected 'screen captures' (digital computer screen images) of webpages of theses ten ENGOs, focusing on their discourses of climate change and personal actions. ${ }^{9}$

I analyzed the data with grounded theory methods, constructing my theories as they emerged from the data and "using constant comparative methods" (Charmaz 2006: 178). Analysis was ongoing, so that I moved back and forth between data collection and analysis, allowing for theoretical sampling (Charmaz 2006: 96); it including open coding (Lofland et al. 2006: 200-1) and more holistic interpretation based on patterns among the interviews (Kleinman et al. 1997: 486). At the start of the study, neither the nature of the environmentalist identities themselves nor the concept of identity work were assumed a priori, but instead emerged and grew from the empirical data itself and were subsequently tested against the data and others' research. The findings are analytically generalizable (Kleinman et al. 1997) to processes that are similar to the links between CFLs and environmentalist identities rather than to populations. I use CFLs and have, in the past, been a member of some of the environmental groups studied. This study shows how identities get tied to ideologies through practices that can seem quite ordinary on the surface. As with others' studies of identity work, the fact that a group of people is using CFLs to accomplish identity work does not mean that they are not using CFLs for other reasons as well.

\section{Generic patterns of green neoliberal identity work}

I found five generic patterns of green neoliberal identity work: people used CFLs to do the subcultural and individual identity work of constructing green neoliberal identities through: 1) celebrations and 2) renunciations of particular technologies; 3) inclusive-talk; 4) performing moral math; and 5) technological progress-talk. I call these patterns "generic" to reflect that while they grew from the case of CFLs, similar patterns can be seen in the ways green neoliberal identity work is done with other things and through other kinds of talk. These generic patterns are similar to Snow and Anderson's (1987) three "generic patterns of identity talk" (distancing, embracement, and fictive storytelling) and Schwalbe and Mason-Schrock's (1996) "four major parts to the process of subcultural identity work" (defining, coding, affirming, policing). In these ways, we can see that buying, using, displaying, and talking about CFLs is similar to other types of identity work found by other researchers studying other identities. Note, however, that these five patterns are not meant to be exhaustive of all kinds of green neoliberal identity work.

\section{Celebrations of particular technologies}

Through the identity work of celebrating the CFL as a technology, people constructed CFLs as a badge of environmentalism, signifying that the moral identity 'environmentalist' is someone who buys 'good' technologies. Groups constructed the environmentalist identity in this way by creating and emphasizing "what you can do" lists and energy audits that teach people how to claim the identity. Nine out of the 'big ten' ENGOs promoted the use of CFLs as a key action people should do to fight climate change. All featured at least one list of 'what you can do' actions to fight climate change on their websites. ${ }^{10} \mathrm{I}$ interviewed three past and present leaders of one NC ENGO that sponsors energy audits of public buildings where members of the public are invited to attend. ${ }^{11}$ All three agreed that in addition to improving the building itself, one of the main purposes of the audits was education, so that people attending would return to their own homes and apply what they had learned. 'What you can do' lists and energy audits are ways that groups teach people what

\footnotetext{
${ }^{8}$ The 'big ten': Defenders of Wildlife, Environmental Defense Fund, Greenpeace USA, National Audubon Society, National Resource Defense Council, National Wildlife Federation, Nature Conservancy, Sierra Club, Wilderness Society, and World Wildlife Fund.

${ }^{9}$ These 'big ten' groups have been faulted as being too corporate and professionalized (e.g., Beder 2002); nonetheless, they influence millions of environmentalists, collect billions of dollars in revenue, and, unlike smaller groups, often have a voice in policy decisions.

${ }^{10}$ Beyond CFLs, the 'what you can do' lists commonly included actions such as planting a tree, buying energy-efficient appliances, and keeping one's car tuned up.

${ }^{11}$ Energy audits are professional assessments of a building's energy use designed to identify ways to use less energy through physically changing the building's design or installing appliances. They usually include replacing incandescent light bulbs with CFLs as one of their recommendations.
} 
actions 'count' toward accomplishing the environmentalist identity and how to enact it, similar to how veteran drug users teach people how to use marijuana (Becker 1953). Like the drug, the CFL acquires a pleasurable meaning for individuals because groups teach them how to celebrate it.

Individuals claimed environmentalist identities by following these lists, attending audits, and overwhelmingly by using CFLs. Fourteen of the fifteen environmentalists interviewed described using CFLs; during participant observation, no one I asked about personal use of CFLs denied using them. When I asked people what things they did in their daily lives that make them think of the environment, they listed their actions in ways that strongly emulate the 'what you can do' lists, suggesting that such lists are powerful resources for identity-making. More than half (8/15) of those formally interviewed had participated in either a group audit of a public building or an audit of their own home. Those who had their homes audited used the information gained as a personalized 'what you can do' list.

CFLs have become one of the most prominent technological signs of environmentalism. Sally, former director of a large NC ENGO, described installing CFLs in a prominent fixture in her home, where she commonly fielded visitors' questions about the importance of CFLs. This installation location invited the questions that allowed Sally to further perform the role of knowing environmentalist to onlookers (and educator, another moral identity tied to environmentalism, for Sally) by celebrating the CFLs. Using a CFL signified that one was committed to everyday environmental actions far beyond light bulbs, while using an incandescent did not, similar to how veils have become signs of broader piety for some Turkish women (Gokariksel 2009). Although some interviewees also spoke lovingly of solar panels, composters, energyefficient cars, and other 'good' technologies they used (or aspired to using), these technologies did not necessarily signify other environmental commitments to the extent that CFLs did. The CFL, more than these other technologies, has become a symbol of energy efficiency and climate change activism more broadly in part because of the symbolic flexibility and power of the light bulb over time.

\section{Renunciations of particular technologies}

Through the identity work of renouncing certain light bulbs, people constructed CFLs, incandescents, and LEDs as morally-significant technologies that signify different types of environmentalists. Through antiincandescent talk, the most common way that study participants did the identity work of renouncing technologies, people could signify themselves as committed environmentalists. Anti-incandescent talk gave the incandescent the meaning 'hypocritical environmental action.' Praising incandescents or talking about them in a favorable way, signified a person as an uncommitted environmentalist. ENGOs commonly coded incandescent use in this way by referring to them as an 'old' technology that belongs in the past. As the Environmental Defense Fund writes, leading up to their CFL promotions:

In the 1880s, light bulbs revolutionized the world. Though we call them 'lights,' traditional incandescent bulbs are actually small heaters that produce a little light - but waste a lot of energy producing heat. Today we can do better. (emphases mine)

In this frame, incandescents cannot signify being a good environmentalist. However, some interviewees still used a mix of incandescents and CFLs in their homes. To repair this breach to their identities, they went out of their way to explain that they used their incandescents only for special tasks (such as needlework) or never turned on those particular lamps.

Participants also did identity work in renouncing technologies through anti-CFL talk. Such talk gave the LED light bulb the meaning 'radical environmental action" and was a way for the speaker to accomplish a more radical environmentalist identity. ${ }^{12}$ At the same time, it made the use of CFLs a sign of being an uncommitted environmentalist. Of the 15 formal interviews, only one person did not use CFLs. Nathan, an

\footnotetext{
${ }^{12}$ By "radical," I follow Raskin et al.'s (2002) distinction between pro-sustainability actions that try to "reform" current political and economic systems through consumption choices and Keynesian policy change on one hand and actions that go beyond reform to also change those systems themselves. Raskin et al. call the latter type of changes "great transitions"; for simplicity and to connect to what are sometimes called more "radical geographies," I call such actions and identities "radical."
} 
active ENGO volunteer, explained that he used LEDs because, as he put it, "Um, I have a social conscience? They're more efficient, you know, better for the planet, less electricity is used. I am slightly less dependent on the grid..." Nathan was renouncing CFLs in favor of consuming LEDs - and speaking of getting off "the grid" - as a way to try to claim a more radical environmentalist identity than what could be accomplished by using the more conventional CFLs. If celebrating CFLs is a key green neoliberal act, rejecting CFLs may appear anti-neoliberal. However, at present these renunciations tend to perpetuate neoliberal subjectivities by continuing to construct the environmentalist as someone who does individualistic, consumptive actions.

Beyond CFLs, many codes of green neoliberal identities are about renouncing particular technological things. As with light bulbs, talk disparaging these technologies helps form identities. For example, I had the following exchange with Bill, a home energy efficiency aficionado, in the middle of our outdoor interview:

Bill: I saw you weren't driving a big SUV. [gestures to where I parked the Corolla]

Interviewer: It's actually not even my car.

Bill: Oh, ok.

Interviewer: I borrowed it!

Bill: [lowering voice conspiratorially] What burns me up about this area is that everybody says, [even softer:] 'oh, we're really environmentally sensitive [louder, sarcastic tone:] but we need to drive around [in] a big SUV, because, you know, we may get into an accident!'

The SUV, like the incandescent bulb, has been coded as a sign of being a 'bad' environmentalist, as a "moral identity" (c.f. Kleinman 1996: 5). Bill has checked to see if I am driving one to see if I follow environmentalist codes. In turn, I was aware, if not consciously (yet), that the rules of environmentalism are that you should minimize driving, so I performed the identity work of renouncing driving by exclaiming that the car is not even mine. The renunciation of particular technological things is pervasive in environmentalist narratives (e.g., "go car-free!" or vilifying coal-fired power plants). This does not mean that all renunciations of technologies support neoliberalism, but rather that such renunciations often are part of making identities, even neoliberal identities.

Inclusive-talk ${ }^{13}$

People used CFLs to define the environmentalist identity as one that everyone can and should claim. ENGOs frequently portray switching to CFLs as one of the easiest actions a person can do for climate change. Four of the big-10 ENGOs especially emphasized the ease of solving climate change through actions like switching to CFLs. Former EPA administrator Stephen L. Johnson rolled out a nationwide CFL promotion by saying, "More and more Americans are seeing the light - that protecting the environment, while saving money, is as easy as changing a light bulb" (Carter-Jenkins 2008). CFLs symbolize this inclusive identity and the message that all actions are important, even small things like changing one's light bulbs. Sarah, director of an NC ENGO, explained her reasoning for focusing on small things:

If you can get them to make one change, then they'll do another, and they'll story-tell about it... They'll do the easy things, like lighting, and then maybe they'll do something harder like give up their cars, and then maybe they'll run for office...

For individuals, the idea that small things make a big difference was implicit throughout the interviews. Hillary, a leader in her church's environmental committee, made this assumption explicit, telling me what difference CFLs can make:

\footnotetext{
${ }^{13}$ I call this type of talk 'inclusive' after Bernstein's (1997) distinction between gay and lesbian social movements that were 'inclusive', aiming "to educate and mobilize a constituency or maximize involvement in political campaigns," while "exclusive" groups often "discourage popular participation."
} 
...it's like, 'if everyone changed 4 bulbs over a period of 3 years, it would be like 800,000 cars removed from-, you know, a million people change, 800,000 cars removed from the streets.' So I mean, collectively it could make a big difference.

The "big difference," for CFLs, was frequently portrayed in terms of these cars off the road or pounds of carbon dioxide reduced.

The idea that claiming the environmentalist identity is easy and only involves small things that make a big difference, dovetails neatly into a larger message that everyone has a role to play in solving environmental problems like climate change. In the websites of the big-10 ENGOs, it is common for 'you' or 'individuals' to be called upon to buy new technologies for our private homes so we produce fewer greenhouse gases (GHGs) in our daily lives. Van, a leader in his church's environmental committee, justified his use of things like CFLs and solar panels by saying:

I think it's just a matter of us doing our part. You know, you may say, 'it's like a drop in a bucket.' But if enough people do this stuff, a drop can fill up a bucket, the bucket becomes a stream, enough stream becomes a river, enough river it becomes an ocean, an ocean a change.

If environmentalists construct an identity that is all-inclusive, easy, about small actions, and about everyone doing their part, then using CFLs can come to signify an 'ordinary person's' environmentalism. This message of what it means to be an environmentalist went far beyond CFLs, as in Van's explanation that he did things as different as changing light bulbs and buying solar panels, which arguably have very different material impacts, for the same reasons.

\section{Performing moral math}

Through the identity work of 'moral math' performances, environmentalists turn the CFL into a morally good technology, signifying that an environmentalist is someone who uses self-education, math, and numbers to make decisions. By 'moral math' performances, I mean the public weighing of numerical pros and cons of environmentally-significant decisions using scientific data, so that particular numbers and mathematical calculations take on moral significance. These calculations are part of a "neoliberal logic" that centers information so that consumers "make proper, socially responsible market decisions" (Roff 2007).

CFLs' mercury issue is a clear example where the environmentalist as an identity is constructed, so that claiming it requires talking in terms of moral math. CFLs contain a small amount of mercury; incandescents do not. Given how much electricity they save, CFLs release net less mercury than incandescents in states with many coal-fired power plants like North Carolina and across the United States as a whole, since burning coal releases mercury (Eckelman et al. 2008). However, several interviewees expressed uncertainty about the mercury in CFLs, suggesting that they were not aware of the research showing that CFLs result in less mercury overall. While few ENGOs mentioned the mercury in CFLs at all, those that did were quick to reassure the reader that, because of weighing the numerical pros and cons, CFLs are still the best lighting technology. Most of the interviewees who mentioned mercury as an issue in their decision-making process told me that in the end they believed that the CFL was the morally good technology to choose.

A second area where discussions of moral math predominated was around the question of whether CFLs make a substantial difference in mitigating climate change. ENGOs nearly uniformly justified the use of CFLs based on numbers that were supposed to hold moral significance, usually accounts of the pounds of carbon dioxide avoided by using them, or the equivalent numbers of imaginary cars that would be kept off the road. Demonstrating knowledge of these numbers and data was a way to claim an environmentalist identity, as when Hillary speaks of the "big difference" it could make, in terms of "800,000 cars removed from the streets" if more people used CFLs (see above). However, the use of these particular CFL calculations to determine if they make a difference is not self-evident. A more straightforward figure than how many cars would be 'removed from the streets' is the percent reduction in national GHG emissions that use of CFLs 
could make. This calculation involves multiplying five numbers: 82.7\% (\% of U.S. GHG emissions from $\mathrm{CO}_{2}{ }^{14}$ ); $94.2 \%$ (\% U.S. $\mathrm{CO}_{2}$ emissions from burning fossil fuels ${ }^{15}$ ); $14.3 \%$ (\% U.S. fossil fuel burning from residential electricity ${ }^{16}$ ); $8.8 \%$ (\% U.S. residential electricity used for lighting ${ }^{17}$ ); and 75\% (\% less electricity that CFLs use ${ }^{18}$ ) to get $0.74 \%$, or the maximum theoretical proportion of U.S. GHG emissions that could be reduced if every U.S. household changed all their bulbs to CFLs.

In four years of research, I never found such a figure calculated or discussed by anyone, including ENGOs, scientists, and activists. No one talks about CFL use as leading to a percentage reduction of national GHG emissions, though that figure offers a clearer indication of the impact of CFLs than other measures. This calculation is not too difficult; interviewees and ENGO websites spoke easily of much more complex calculations. The $0.74 \%$ figure is a significant patterned absence that strongly suggests that the figures that are used by environmentalists to justify the use of CFLs are more about performing moral identities than about what constitutes significant change. Likely the $0.74 \%$ figure is so low that if the figure were widespread knowledge, it would feel dissonant to perform green identities by using CFLs. ${ }^{19}$ However, this does not mean that using CFLs has no meaning for people or that they do not use them for other reasons. Rather, it suggests that although it may appear from moral math-talk about 'cars off the road' that environmentalists use CFLs because they are making a substantial impact on GHG emission, the patterned absence of the $0.74 \%$ figure makes it more likely that the meaning of CFLs is about the ease with which people can use them in the types of identity work described in this article.

Talking about CFLs using moral math grounds the environmentalist identity in self-education about numbers and data. Similar dynamics occur in the epic 'cloth versus disposable diaper' or 'paper vs. plastic bag' debates among environmentalists. Brianna, an interviewee without ties to environmental groups, explains her decision in another longstanding debate, over whether it is more environmentally-friendly to hand- or machine-wash your dishes:

I finally did some reading and found out the dishwasher [versus] by hand, it was kind of a wash, so [we] just use the dishwasher. [sounding defensive:] Um, I pay attention. I try to find out what is the better choice.

An environmentalist is constructed as someone who cares about these minutiae, and scientific data are the guiding light for determining morally right individual actions. But not all data count.

\section{Technological progress-talk}

Environmentalists constructed and claimed identities by talking about their past and future uses of technologies in a frame of technological progress; this talk coded an environmentalist as someone who uses technology progressively. Snow and Anderson (1987) found that identity-talk by homeless people commonly took the form of "fictive storytelling" about their past and future selves. I found similar patterns of talk among environmentalists, especially the narrative that environmentalists are people who choose better and better technologies based on learning about new scientific data.

Environmentalists talked about their past use of CFLs in two main ways, both centering narrations of technological progress and self-education. Some interviewees claimed they had been using CFLs from the moment they first heard of them and spoke of always having been good environmentalists. Others spoke of acting in 'bad' ways toward the environment in the past, which they rectified when they learned better. For

\footnotetext{
${ }^{14}$ In 2012; after changing all gases into equivalent units of $\mathrm{CO}_{2}$, called "CO 2 eq." (U.S. EPA 2014: ES-8).

${ }^{15}$ In 2012 (U.S. EPA 2014: ES-8).

${ }^{16}$ In 2012 (U.S. EPA 2014: ES-11); the figure is a result of the author dividing the $\mathrm{CO}_{2} \mathrm{eq}$ emissions from residential electricity (725.8Tg $\mathrm{CO}_{2} \mathrm{eq}$ ) by the total $\mathrm{CO}_{2} \mathrm{eq}$ emissions in the U.S. (5065.7 $\mathrm{Tg} \mathrm{CO}_{2} \mathrm{eq}$ ) within the category of fossil fuel combustion.

${ }^{17}$ In 2001, the most recent date that such data is available; includes indoor and outdoor lighting in 2001 (U.S. EIA 2001).

${ }^{18}$ Average; compared with incandescents (U.S. EPA 2008).

${ }^{19}$ Even academic audiences have resisted this figure. One grant reviewer, for example, wrote that I could not assume the $\sim 1 \%$ figure was accurate without first establishing it through peer-reviewed research.
} 
example, Sandy, an environmental leader in her church, explained with some embarrassment that "before I knew better", she had disposed of CFLs by putting them in the trash, rather than following the extensive EPA guidelines for handling them as a toxic substance.

Another way that people claimed environmental identities through technological progress-talk was through discussion of using a technology more or in better ways in the future. This type of talk was used to repair environmentalist identities. For example, early in my interview with Hillary, she told me she had replaced nearly every bulb in her house with CFLs. Later, while giving me a tour of her home, she expressed surprise as she noticed that she had many fewer CFLs installed than she had thought. Her response was to use talk about future CFL use to repair this identity breach, declaring, "Now that I know this, I can come up today and change it." Similarly, when I asked people about what sorts of environmentally-significant actions they do now, they often responded by telling me about what they plan to do once they know or earn more.

Technological progress-talk about choosing and using CFLs progressively better was primarily individual identity work, but it echoes larger environmentalist discourses of progress. The example (see above) from the Environmental Defense Fund's narration of "traditional incandescent bulbs" that were inefficient, but "today we can do better" (with CFLs) was a clear instance of this with lighting technologies. Communication scholars have shown how the 'apocalyptic narrative' has been common in environmentalism for decades. As Killingsworth and Palmer (1996) explain:

In depicting the end of the world as a result of the overweening desire to control nature, activists have discovered a rhetorical means of contesting their opponents' claims for the idea of progress with its ascendant narrative of human victory over nature.

They argue that in climate change mitigation movements, activists have brought the apocalypse discourse back to the public but without attacking progress wholeheartedly, because of environmentalists' generally high education levels and regard for science. My findings suggest that the emphasis of the technological progress narrative on green technologies as improving over time, continues in people's identity work with CFLs. This narrative of technological progress is also found in the ways that people talk about the environmental impacts of power plants, as when 'old' coal-fired plants are depicted as less environmentally friendly than 'new' wind turbines.

The data revealed five generic patterns in the ways that people talk about using things like CFLs to construct neoliberal environmental subjectivities. Through this green neoliberal identity work, CFLs were given multiple meanings: badge of environmentalism, easy action, big change in a small package, morally good technology, and progressive technology. By giving CFLs these meanings, the environmentalist was constructed as someone who buys 'good' technologies, renounces 'bad' technologies, performs small actions, self-educates, uses math/numbers to make decisions, and uses technology progressively. Even though this sometimes produced a range of 'environmentalists', from an uncommitted to a radical to an 'ordinary person' environmentalist, these identities can be seen as variations within the green neoliberal identity. Even when the environmentalist was defined as a 'radical' through these types of identity work (for example Nathan renouncing CFLs in favor of LEDs), the identity was still focused on individualistic, consumptive actions: buying green technologies to solve environmental problems.

\section{Implications}

Framing environmental subject formation in terms of five generic micro-level processes of green neoliberal identity work has two main implications:

1) it adds to our understanding of how people become environmentalists, showing some of the micro-level processes through which green neoliberal ideologies are linked to everyday neoliberal environmentalist practices; 
2) it can help scholars and activists to better understand resistance to neoliberal logics.

Instead of emphasizing the green neoliberal identity as a static, already-formed entity, this framing underscores how such an identity is a process where the environmentalist as a subject is continuously being produced and reproduced, accomplished and re-accomplished.

\section{Green neoliberal subjects form themselves through patterns of identity talk}

Using an SI framework adds to our understanding of the mechanisms through which neoliberal ideologies are linked to environmentalist practices. Through the subcultural identity work of celebrating CFLs and renouncing incandescents on 'what you can do lists', portraying using CFLs as an easy way to effectively combat climate change available to anyone, highlighting particular mathematical relationships rather than others, and portraying technological change as progressive, ENGO websites and leaders of ENGOs create some of the resources available to individuals to make and claim environmentalist identities. The identities available to be claimed by individuals are thus limited by this subcultural identity work, which is in turn constrained by broader power relations and discourses. In this way, larger neoliberal ideologies can get translated into individual environmentalist practices through subcultural identity work that in turn influences the range of individual identity work available to be performed. The individual identity work, in turn, helps to create the subcultural identity work that reproduces the neoliberal ideologies. How ENGOs thus frame the possibilities for action can thus have an impact on what environmentalist practices are performed in part because it signals how to properly make and claim valued identities.

Rather than suggesting that environmentalists are dupes who unwittingly use technologies that make only a small difference in GHG emissions, the findings of this study suggest that environmentalists who use CFLs do so because they are meaningful in other ways. CFLs are partly meaningful to environmentalists because they are conducive to such moral math (and other identity talk) discussions through which desirable identities can be made and claimed. Because 'environmentalist' is a moral identity, fulfilling the codes and rites of affirmation, making and remaking oneself into this identity has become part of enacting a 'good' self (Kleinman 1996: 5).

A critical political economy analyst, or a political ecologist, might ask, "What do environmentalists do for the neoliberal environmental project by using and promoting CFLs?" and conclude that environmentalists perpetuate capitalism and neoliberal ideologies through their CFL actions. Yet it is important also to ask, as SI scholars might, "What do environmentalists do with the CFL?" I argue that environmentalists use the CFL to claim and construct their identities. CFL use and promotions do work for capitalism and for people. Environmentalists make these identities, drawing on symbolic and other resources from ENGOs, environmental scientists, politicians, and others who, with the rise of neoliberal environmentalism, are increasingly producing identity-making resources that embody neoliberal ideals. People help produce themselves as particular kinds of subjects through identity work, but the identities available to them and the resources of making those identities are limited by broader power relations.

What little work has been done to understand environmentalist identity work suggests that it centers on the consumption and display of material objects (light bulbs, bicycles, hybrid cars, etc.). However, the current study suggests that identity talk about the things can be a particularly important form of identity work for environmentalists. Although the methods of the current study made it easier to observe talk than the display/use of CFLs, the extent to which people talked about CFLs and the kinds of stories they told about them suggest that CFL talk was an important part of identity construction through light bulbs. Many of the stories people told me about CFLs were stories about their verbal interactions with other people about CFLs. Instead of materiality being paramount on its own, then, the findings of this research suggest that part of the reason why the objects of environmental practice are so important to identity construction (as others have found) is because they enable the identity talk that is another part of identity construction.

Talk is likely to be particularly important to the ways that neoliberal environmentalists form themselves as subjects because it renders environmental practices visible, which is of particular importance to green neoliberal identity work. Green neoliberal practices are often individualistic, private, and consumptive (although not all are: for example, driving a Toyota Prius is individualistic and consumptive, but much more 
public than using a CFL). As such, it can be difficult to make identities with them except by talking about them. How is one to perform identity if the marker of that identity is a light bulb in one's closet? How does one claim a more radical environmentalist identity if no one sees you buy the LED? Since identityconstruction is a social process, it requires that at least part of the time, the identity-claimant has an audience. This does not mean all identity work is done with a live audience or that environmental practices do not become private habits, but only that identity talk can take on new importance for the making and claiming of identities where the identity work is overwhelmingly focused on hidden, private, individualistic behaviours, and based on consumption, as it is in the making of green neoliberal subjects.

Through this identity talk as well as the display of the material objects of environmentalism, neoliberal environmentalists form themselves as subjects. The concept of identity work makes the abstract forces of 'enrolment' and 'interpellation' more concrete by making visible an agent and the mechanisms of subject formation. Some of the important agents in these processes are environmentalists, environmental leaders, and ENGOs themselves, working alone and with others to construct what an environmentalist means and does through subcultural and individual identity work.

\section{Toward critical green identity work}

Understanding the micro-level processes through which neoliberal environmentalists are made, also adds to scholars' and activists' understandings of resistance to neoliberal environmental projects. Scholars have called for a remaking of green subjectivities to be more resistant to neoliberalism (e.g., Slocum 2004a). Since identities are continuously made and remade, they can be constructed and performed differently. One way to do them differently is to change the meanings of the things involved in subject formation through different identity talk. Looking at green neoliberal identity work as a process, rather than green neoliberal identities as static, already-complete entities, opens up new points of resistance through critical green identity work. I propose 'critical' green identity work as a process of creating identities which resist neoliberal drives toward individualism, privatization, accumulation of capital by a few, and instead emphasizes social justice. This may complement calls for a more reflexive consumer-citizen (Slocum 2004a; Johnston and Szabo 2011) and moves toward more conscious makings and continuous re-imaginings of environmentalist subjectivities by groups and individuals. It raises questions about whether environmentalism should be about celebrating or rejecting particular technologies, each person making the same changes, easy actions, applying math to small choices between technologies and practices, and technological progress. While I saw glimmers of this type of identity work in the field, often peoples' ideas about social justice did not translate into identity construction. Although the relationship between neoliberal ideologies and the use of CFLs is likely to be complex for individuals, the data in this study and others' research suggest that current emphases on the consumption of CFLs is unlikely to resist neoliberal environmental projects, in part by taking energy away from other activities. I propose two types of examples of critical green identity work based on the current study. They are not meant as exhaustive of the possibilities for critical green identity work, but as ways to begin to open up the production of green subjects through the concept of identity work.

First, environmentalists could embrace CFLs' current status as a central badge signifying commitment, and re-imagine the CFL as a Trojan horse, re-making its meaning so it better resists neoliberal environmental projects. Scholars have shown that some identity work can be 'oppressive', as when people make and claim their identities in ways that 'Other' people not in their group (Schwalbe and Mason-Schrock 1996). For example, Ezzell (2009) found that female rugby players attempting to manage sexism and homophobia often reinforce these systems of inequality by performing identity work that Others non-rugby playing women. Yet identity work might also be used as part of larger social justice projects. One way to do this would be to emphasize the question "are CFLs just?" in the constructions of environmentalist identities, rather than "are CFLs better for the environment?" By 'just' I mean to highlight questions of who benefits and who loses in discussions of CFLs; at present, such questions are mainly implied: there appears to be an implicit idea that reducing GHG emissions would be helpful for people, but who those helped people are and where they live, as well as how they might be impacted by some of the downsides of CFLs, is not discussed in relation to CFLs. At present, environmental discourses about CFLs focus instead on the question of whether CFLs are better for the environment, so people do identity work by discussing milligrams of mercury, pounds of carbon 
dioxide, and life cycle analyses. These are all likely to be components in a discussion of the environmental justice implications of CFLs, but at present they are not explicitly linked to people's lives.

In contrast, asking "Are CFLs just?" focuses the discussion on what kind of world environmentalists want for the future, begging questions of "just for whom?" and "just where?" It focuses attention on considering what a just world might look like and how environmentalists will go about deciding whether it is just before considering questions of mercury and $\mathrm{CO}_{2}$, which are likely to be important data points in such a discussion. Just as Wolford (2007) showed that a reliance on "moral reasoning" could be an act of resistance to neoliberal logics by the MST in Brazil, so could questions of the justice of technologies like light bulbs be classified as resistance. It might cause environmentalists to discuss the political economic history of CFLs and whether they can really be considered 'progress' if they have more of some kinds of environmental impacts than their predecessors. It might go some small way toward Slocum's (2004b) reworking of Haraway (2000, page 105, cited by Slocum): "climate politics...ought to 'make visible all those things that have been lost in an object"', which are, in many ways, questions of social justice as well as environmental impacts. The actual social justice implications of CFLs, which are likely to be complex, may be less important here than the discussion of justice questions. In these ways, the seemingly quintessential neoliberal object could be used to resist neoliberalism when activists use it to make identities differently.

The second example of critical green identity work is to create alternative identity badges for the environmentalist. Other technological badges are the most obvious alternative. One interviewee, Stephanie, who was perhaps the least interested in CFLs of all the interviewees, spoke of wanting to invest in solar panels with her neighborhood. Cooperative purchases like this might be less individualistic performances of identity than CFLs and potentially unravel some of the business-as-usual assumptions in CFLs. But there are clearly problems with many kinds of techno-badges, especially because they tend to be expensive, often laced with prohibitive cultural capital, and, as Feenberg (1991: 65) argues, inventing new and more technologies can still help reproduce the capitalist system. It is easy to slip from vilification of one technology to treating another as a savior, when really it is the social relations, in addition to environmental impacts, that matter.

Staying within the light bulb box, what might happen if talk about an imaginary lighting technology were constructed as the badge of environmentalism? There is no reason why an identity badge needs to be material, given the importance of talk to green identity work. Environmentalists might create a new, imaginary light bulb that represents the perfect technology from a sustainability standpoint: it lasts forever, uses no energy, and is made of no toxic or nonrenewable materials. Claiming environmentalist identities might be positioned as something one does by talking in certain ways about this imaginary technology. This sort of thought experiment can raise key questions about what it means to be an environmentalist and what sorts of endgames environmentalists are aiming at. Setting aside physics problems, what might be the economic incentives and disincentives in the capitalist system to inventing such a light bulb? Who would benefit and who would lose from such a commodity? Where and when? Such thought experiments can raise important critiques of the present system by showing the contradictions within hopes for 'greening' capitalist systems (O'Connor 1997; Polanyi 2001). And those are the sorts of questions that might begin to unravel the hold neoliberal logics have on environmentalist imaginaries, which could be seen, for example, in the ways many of the interviewees vilified corporations but did not talk about the incentive systems of capitalism as a political economic structure, or how to change that structure for the better.

\section{Conclusions}

I began by theorizing green neoliberal identity work as a process through which groups and individuals construct and claim neoliberal environmentalist subjectivities, bringing together the perspectives of critical green neoliberalism and symbolic interactionism. Together, such perspectives add to our understanding of how neoliberal ideologies are linked to everyday environmentalist practices such as changing a light bulb. The case study of a quintessential green neoliberal technology, the CFL, brought to the fore five generic processes of green neoliberal identity work. These patterns of identity work add to our understanding of how people become environmentalists and can help scholars and activists alike to better understand resistance to neoliberal logics within environmentalism. 
Similar generic processes are likely to be at work in the formation of other kinds of neoliberal subjects, including ethical food consumer-subjects who 'shop for change.' These processes likely are also at work as green neoliberal subjects use and talk about other things they code as environmentally 'good' and 'bad' in their everyday lives including bicycles, energy-efficient refrigerators, and hybrid cars on one hand and SUVs, air conditioners, and garbage bins on the other. More research is needed to better understand the socialpsychological mechanisms through which ideologies are linked to everyday practices for neoliberal subjects, and how subcultural identity work creates the resources from which identities are made and claimed.

\section{References}

Agrawal, A. 2005. Environmentality: technologies of government and the making of subjects. Durham, NC: Duke University Press.

Aquino, K. and A. Reed, II. 2002. The self-importance of moral identity. Journal of Personality and Social Psychology 83(6): 1423-1440.

Bakker, K. 2005. Neoliberalizing nature? Market environmentalism in water supply in England and Wales. Annals of the Association of American Geographers 95(3): 542-565.

Bakker, K. 2010. The limits of 'neoliberal natures': debating green neoliberalism. Progress in Human Geography 34(6): 715-735.

Bamberg, S. and G. Moser. 2007. Twenty years after Hines, Hungerford, and Tomera: a new meta-analysis of psycho-social determinants of pro-environmental behavior. Journal of Environmental Psychology 27: 14-25.

Barnett, C., N. Clarke, P. Cloke, and A. Malpass. 2008. The elusive subjects of neo-liberalism. Cultural Studies 22(5): 624-653.

Becker, H.S. 1953. Becoming a marijuana user. The American Journal of Sociology 59(3): 235-242.

Beder, S. 2002. Global spin: the corporate assault on environmentalism. Revised edition. White River Junction, VT: Chelsea Green Publishing Company.

Bernstein, M. 1997. Celebration and suppression: the strategic uses of identity by the lesbian and gay movement. American Journal of Sociology 103: 531-565.

Bladh, M. and H. Krantz. 2008. Towards a bright future? Household use of electric light: a microlevel study. Energy Policy 36: 3521-3530.

Blumer, H. 1969. Symbolic interactionism: perspective and method. Berkeley, CA: University of California Press.

Center for Media and Democracy. 2011. SourceWatch: big green. [accessed April 27 2011]. http://www.sourcewatch.org/index.php?title=Big_Green.

Charmaz, K. 2006. Constructing grounded theory: a practical guide through qualitative analysis. Thousand Oaks, CA: Sage.

Creyts, J., Derkach, A., Nyquist, S., Ostrowski, K., and Stephenson, J. 2007. Reducing U.S. greenhouse gas emissions: How much at what cost? McKinsey and Company Executive Report. [accessed 24 Apr. 2010]. http://www.mckinsey.com/clientservice/sustainability/pdf/US_ghg final_report.pdf.

Dowling, R. 2010. Geographies of identity: climate change, governmentality and activism. Progress in Human Geography 34(4): 488-495.

Eckelman, M.J., P.T. Anastas, and J.B. Zimmerman. 2008. Spatial assessment of net mercury emissions from the use of fluorescent bulbs. Environmental Science and Technology 42: 8564-8570.

Emerson, R.M., R.I. Fretz, and L.L. Shaw. 1995. Writing ethnographic fieldnotes. Chicago: University of Chicago Press.

Ezzell, M.B. 2009. "Barbie dolls" on the pitch: identity work, defensive othering, and inequality in women's rugby. Social Problems 56(1): 111-131.

Feenberg, A. 1991. Critical theory of technology. New York: Oxford University Press.

Foucault, M. 1976[2007]. The meshes of power. In J.W. Crampton and S. Elden (eds.) Space, knowledge and power: Foucault and geography. Burlington, VT: Ashgate. Pp 153-162. 
Foucault, M. 1977[1995] Discipline and punish: the birth of the prison. New York: Vintage Books.

Guldbrandsen, T.C. and D.C. Holland. 2001. Encounters with the super-citizen: neoliberalism, environmental activism, and the American Heritage Rivers Initiative. Anthropological Quarterly 74(3): 124-134.

Guthman, J. and M. DuPuis. 2006. Embodying neoliberalism: economy, culture, and the politics of fat. Environment and Planning D: Society and Space 24: 427-448.

Gokariksel, B. 2009. Beyond the officially sacred: religion, secularism, and the body in the production of subjectivity. Social and Cultural Geography 10(6): 657-674.

Hajer, M.A. 1995. The politics of environmental discourse: ecological modernization and the policy process. Oxford: Clarendon Press, Oxford.

Harvey, D. 2005. A brief introduction to neoliberalism. Oxford: Oxford University Press.

Heynen, N., J. McCarthy, S. Prudham, and P. Robbins. 2007. Neoliberal environments: false promises and unnatural consequences. London: Routledge.

Hinchliffe, S. 1996. Helping the earth begins at home: the social construction of socio-environmental responsibilities. Global Environmental Change 6(1): 53-62.

Hobson, K. 2013. On the making of the environmental citizen. Environmental Politics 22(1): 56-72.

Horton, D. 2003. Green distinctions: the performance of identity among environmental activists. The Sociological Review 51(Issue Supplement s2): 63-77.

Hunt, S.A., and R.D. Benford. 1994. Identity talk in the peace and justice movement. Journal of Contemporary Ethnography 22(4): 488-517.

Johnston, J. and M. Szabo. 2011. Reflexivity and the Whole Foods Market consumer: the lived experience of shopping for change. Agriculture and Human Values 28: 303-319.

Katz, C. 2005. Partners in crime? Neoliberalism and the production of new political subjectivities. Antipode 37(3): 623-631.

Killingsworth, M.J. and J.S. Palmer. 1996. Millennial ecology: the apocalyptic narrative from Silent Spring to Global Warming. In C.G. Herndl and S.C. Brown (eds.) Green culture: environmental rhetoric in contemporary America. Madison: University of Wisconsin Press.

Kleinman, S. 1996. Opposing ambitions. Chicago: University of Chicago Press.

Kleinman, S., M.A. Copp, and K.A. Henderson. 1997. Qualitatively different: teaching fieldwork to graduate students. Journal of Contemporary Ethnography 25(4): 469-499.

Larner, W. 2003. Neoliberalism? Environment and Planning D: Society and Space 21: 509-512.

Lofland, J., D. Snow, L. Anderson, and L.H. Lofland. 2006. Analyzing social settings: a guide to qualitative observation and analysis. $4^{\text {th }}$ edition. Belmont, CA: Wadsworth.

McCarthy, J. 2007. Privatizing conditions of production: trade agreements as neoliberal environmental governance. In N. Heynen, J. McCarthy, S. Prudham, and P. Robbins (eds.) Neoliberal environments: false promises and unnatural consequences. London: Routledge. Pp 38-50.

McCarthy, J. and S. Prudham. 2004. Neoliberal nature and the nature of neoliberalism. Geoforum 35: 275283.

MOMA, Museum of Modern Art, New York, NY. 2012. Exhibition: electric currents, 1900-1940. [accessed Nov 7 2012]. http://www.moma.org/visit/calendar/exhibitions/1261.

Nye, D.E. 2010. When the lights went out: a history of blackouts in America. Cambridge, MA: MIT Press.

O'Connor, J. 1997. Natural causes: essays in ecological Marxism. New York: Guilford Press.

Polanyi, K. 2011[1944]. The great transformation: the political and economic origins of our time. Boston: Beacon Press.

Prudham, S. 2007. Poisoning the well: neoliberalism and the contamination of municipal water in Walkerton, Ontario. In N. Heynen, J. McCarthy, S. Prudham, and P. Robbins (eds.) Neoliberal environments: false promises and unnatural consequences. London: Routledge. Pp 163-176.

Raskin, P., T. Banuri, G. Gallopín, P. Gutman, A. Hammond, R. Kates, and R. Swart. 2002. Great transition: the promise and lure of the times ahead. Boston: Stockholm Environmental Institute. 
Robbins, P. 2007. Lawn people: how grasses, weeds, and chemicals make us who we are. Philadelphia: Temple University Press.

Roff, R.J. 2007. Shopping for change? Neoliberalizing activism and the limits to eating non-GMO. Agriculture and Human Values 24: 511-522.

Rutland, T. and A. Aylett. 2008. The work of policy: actor networks, governmentality, and local action on climate change in Portland, Oregon. Environment and Planning D: Society and Space 26: 627-646.

Sandahl, L.J., Gilbride, T.L., Ledbetter, M.R., Steward, H.E., and Calwell, C. 2006. Compact fluorescent lighting in America: lessons learned on the way to the market. U.S. DOE and Pacific Northwest National Laboratory. [accessed 10 Jan. 2014]. http://apps1.eere.energy.gov/buildings/publications/pdfs/ssl/cfl_lessons_learned_web.pdf.

Saunders, C. 2008. Double-edged swords? Collective identity and solidarity in the environment movement. British Journal of Sociology 59(2): 227-253.

Schwalbe, M.L. and D. Mason-Schrock. 1996. Identity work as group process. Advances in Group Processes 13: 113-147.

Shove, E. and Walker, G. 2010. Governing transitions in the sustainability of everyday life. Research Policy 39: 471-476.

Slocum, R. 2004a. Consumer citizens and the Cities for Climate Protection campaign. Environment and Planning A 36: 763-782.

Slocum, R. 2004b. Polar bears and energy-efficient lightbulbs: strategies to bring climate change home. Environment and Planning D: Society and Space 22: 413-438.

Smith, J. 2013. Creating a godless community: the collective identity work of contemporary American atheists. Journal for the Scientific Study of Religion 52(1): 80-99.

Snow, D.A. and L. Anderson. 1987. Identity work among the homeless: the verbal construction and avowal of personal identities. American Journal of Sociology 92(6): 1336-1371.

Stern, P.C. 2000. Toward a coherent theory of environmentally significant behavior. Journal of Social Issues 56(3): 407-424.

Thoyre. A. 2011. Social capital as a facilitator of pro-environmental actions in the USA: a preliminary examination of mechanisms. Local Environment 16(1): 37-49.

U.S. DOE, Department of Energy. 2009. ENERGY STAR CFL market profile. [accessed 1 May 2010]. http://www.energystar.gov/ia/products/downloads/CFL_Market_Profile.pdf.

U.S. EIA, Energy Information Administration. 2001. End-use consumption of electricity 2001. [accessed July 18 2013]. http://www.eia.gov/emeu/recs/recs2001/enduse2001/enduse2001.html.

U.S. EPA, Environmental Protection Agency. 2008. Frequently asked questions: information on compact fluorescent light bulbs (CFLs) and Mercury. [accessed May 6 2010]. http://www.energystar.gov/ia/partners/promotions/change_light/downloads/Fact_Sheet_Mercury.pdf.

U.S. EPA, Environmental Protection Agency. 2011. Inventory of U.S. greenhouse gas emissions and sinks: 1990-2009: $\quad$ Executive $\quad$ summary. $\quad$ [accessed June $28 \quad 2013$ ]. http://www.epa.gov/climatechange/Downloads/ghgemissions/US-GHG-Inventory-2011-ExecutiveSummary.pdf.

U.S. OAR, Office of Air and Radiation. 2008. EPA and DOE spread a bright idea: Energy Star light bulbs are helping to change the world. [accessed $\quad$ May 7 2010]. http://yosemite.epa.gov/opa/admpress.nsf/7ebdf4d0b217978b852573590040443a/970f05bf0bc5d9aa8 52573d10055b38d!OpenDocument.

Wolford, W. 2007. Neoliberalism and the struggle for land in Brazil. In N. Heynen, J. McCarthy, S. Prudham, and P. Robbins (eds.) Neoliberal environments: false promises and unnatural consequences. London: Routledge. Pp 243-254. 